\title{
Genetic variability and phylogenetic analysis of Lagovirus europaeus strains GI.1 (RHDV) and GI.2 (RHDV2) based on the RNA-dependent RNA polymerase (RdRp) coding gene
}

\author{
Beata Hukowska-Szematowicz ${ }^{\square}$ \\ Institute of Biology, University of Szczecin, Szczecin, Poland; Molecular Biology and Biotechnology Center, University of Szczecin, \\ Szczecin, Poland
}

Lagovirus europaeus GI.1 (RHDV-rabbit haemorrhagic disease virus) and GI.2 (RHDV2-rabbit haemorrhagic disease virus 2), family Caliciviridae, genus Lagovirus, are etiological factors of the rabbit haemorrhagic disease (RHD). This small RNA virus is a great model for tracking the variability and evolution of RNA viruses, because it uses an RNA-dependent RNA polymerase (RdRp) to replicate its own genetic material. This polymerase determines the fidelity and the rates of replication and mutation of the virus, conditioning its adaptation to the environment and even to a new host, and thus influencing evolution of the virus. The aim of this study was to determine the genetic variability and phylogenetic relationships of 105 Lagovirus europaeus strains with different genotypes based on the RdRp gene. The strains came from around the world in the years of 1987-2017. The aforementioned group of 105 strains included 14 strains whose RdRp sequences were obtained and analysed in this study, and the rest were retrieved from GenBank: 74 strains classified as genotype GI.1 (RHDV), 14 as Gl.2 (RHDV2), 2 strains of Lagovirus europaeus not assigned to any genotype, and a MRCV strain, the sequences of which were collected from GenBank. Among the 14 strains whose RdRp sequences were obtained in this study, the highest variability was presented in the Austrian 237 strain from 2004. The genetic distance between the Austrian 237 strain and the remaining thirteen analysed strains ranged from 0.117 to 0.123 (from $11.7 \%$ to $12.3 \%$ nucleotide substitutions). The lowest variability, however, was recorded for Hungarian, Czech and Austrian strains. On the phylogenetic tree, the 14 analysed strains were allocated into GI.1c (G2), GI.1d (G3-G5) and GI.1a (RHDVa). Analysis of the genetic variability of the 105 strains of Lagovirus europaeus indicated a growing genetic distance between the strains, both in time and location. Phylogenetic analysis showed a division of the strains into seven groups, dictated by the chronology, geographical location and evolutionary events in the history of the virus, such as mutations and recombinations.

Key words: RdRp, Lagovirus europaeus, RHDV, RHDV2, rabbit, variability, phylogenetic analysis

Received: 13 January, 2020; revised: 07 February, 2020; accepted: 08 February, 2020; available on-line: 04 March, 2020

凶e-mail: beata.hukowska-szematowicz@usz.edu.pl

Abbreviations: RHDV, rabbit haemorrhagic disease virus; RHDV2, rabbit haemorrhagic disease virus 2; RdRp, RNA-dependent RNA polymerase; RHD, rabbit haemorrhagic disease; RHDVa, rabbit haemorrhagic disease virus-antigenic variant; VP, viral protein; RCV rabbit calicivirus; MRCV, Michigan rabbit calicivirus

Accession numbers for new nucleotide sequences reported in this manuscript: MN218422, MN218423, MN218424, MN218425,
MN218426, MN218427, MN218428， MN218429, MN218430 MN218431, MN218432, MN218433, MN218434, MN218435

\section{INTRODUCTION}

Lagovirus europaeus genotype GI.1 (RHDV) and GI.2 (RHDV2/b) are etiologic factors of Rabbit Haemorrhagic Disease (RHD), belonging to the Caliciviridae family, Lagovirus genus. The disease was recorded for the first time in 1984 in China, in the Jiangsu Province, in rabbits imported from Germany (Liu et al., 1984). In less than a year, the disease had spread across China, causing rabbit deaths on a massive scale (Liu et al., 1984). In Europe, the disease was first reported in Italy in 1986; with further occurrences recorded in Czechoslovakia in 1987, in Germany in 1988, in France and Spain in 1989, and at the turn of 1988 in Poland (Hukowska-Szematowicz et al., 2013). The RHDV strains isolated in the earliest period of RHDV occurrence in Europe (1987-1989) were characterised with high homology and low genetic variability among one another, and are referred to as the reference strains, and include the Czech V351 strain from 1987, as well as strains from 1989: German FRG, Spanish AST89, French SD, and Italian BS89. In 1996, the first case of RHDV was recorded (Capucci et al., 1998), which was different from classic RHDV in the aspect of antigenicity, genetic variability and phylogenetic analysis of the gene encoding structural protein VP60, referred to as RHDVa (Capucci et al., 1998; Kerr et al., 2009; Kinnear \& Linde, 2010; Fitzner \& Niedbalski, 2017). It was also evidenced that RHDVa strains are characterised with higher virulence and mortality rates in rabbits (Capucci et al., 1998). Continuous monitoring points out that in some areas, RHDVa seems to replace RHDV, as is currently being observed in Australia (Mahar et al., 2018b). Phylogenetic surveys have classified the RHDV strains into six genogroups (G1-G6) (Le Gall-Recule et al., 2003), while recently, they have been allocated into four variants of Lagovirus europaeus GI.1 (RHDV): GI.1a (previously G6/RHDVa), GI.1b (previously G1), GI.1c (previously G2), GI.1d (previously G3-G5), according to a newly proposed nomenclature (Le Pendu et al., 2017).

A breakthrough in RHDV evolution involved the occurrence in 2010 of a new genotype in France (Le GallRecule \& Zwingelstein, 2011) which, within the framework of the newly proposed nomenclature, was referred to as Lagovirus europaeus-GI.2 (RHDV2/b) (Le Pendu et al., 2017). RHDV2 has spread to other countries: Italy (Le Gall-Recule et al., 2013), Spain (Dalton et al., 2012), Portugal (Abrantes et al., 2013), United Kingdom (Westcott et al., 2014), Scotland (Baily et al., 2014), the Azores 
(Duarte et al., 2015), Australia (Hall et al., 2015), Macaronesia (Lopes et al., 2018), Poland (Fitzner \& Niedbalski, 2018) and Tunisia (Rahali et al., 2019). Continuous monitoring suggests that in many areas it replaces the older locally circulating strains, such as GI.1b (G1), G1.1c (G2), GI.1d (G3-G5), and GI.1a (RHDVa) (Le Gall-Recule et al., 2013; Calvete et al., 2014; Dalton et al., 2014; Lopes et al., 2015a; Mahar et al., 2018a; Rouco et al., 2018). RHDV2 shows greater genetic variability than between RHDVa and classic RHDV, with a similarity of nucleotide sequence of the VP60 gene between wild-type RHDV2 and RHDV of approximately 82\% (Dalton et al., 2012; Le Gall-Recule et al., 2013). Studies on RHDV pathogenesis caused by RHDV2 have revealed that the disease lasts longer, with the virus having lower virulence and causing lower mortality than recorded after infection with RHDV. Furthermore, RHDV2 can cause infection not only in young rabbits, including those aged 11 days (Dalton et al., 2012), which used to be considered resistant to the old RHDV genotypes; but also in vaccinated rabbits (Le Gall-Recule et al., 2013), which has also been confirmed in Poland (Fitzner \& Niedbalski, 2018). It was also evidenced that RHDV2 causes diseases in other lagomorph species, including the Sardinian Cape hare (Lepus capensis mediterraneus) (Puggioni et al., 2013), Corsican (Italian) hare (Lepus corsicanus) (Camarda et al., 2014), Iberian hare (Lepus granatensis) (Lopes et al., 2014) and European hare (Lepus europaeus) (Hall et al., 2017), and recently even in the mountain hare (Lepus timidus) (Neimanis et al., 2018) and hares in England (Bell et al., 2019), unlike RHDV and RHDVa, which are believed to be characteristic for the European rabbit (Oryctolagus cuniculus). The latest case of infection is the sixth Lepus species to be infected with RHDV2, which suggests that the susceptibility to RHDV2 can be widespread among the Lepus species (Neimanis et al., 2018; Bell et al., 2019). Holms and Grenfell (Holms \& Grenfell, 2009) explain that the occurrence of new variants of the virus in the wild is the result of four factors: (1) adaptive evolution of the host's genes that engage in the most thorough interaction with the host's immune response, and react at the "host-pathogen" level, (2) interaction among the locally circulating viruses, (3) possible outbreak dynamics in time and space, and (4) disease spread control methods. Hypothetically, it can be assumed that in the case of RHDV, we are dealing with all four factors.

Since the isolation of RHDV more than 30 years ago, the genetic variability and evolution of RHDV have shown a specificity in the RdRp enzyme used by the virus to replicate its own genetic material and to express its genome. The enzyme has no corrective ability to repair the many errors generated during the replication process (Chen et al., 2003). RdRp determines the fidelity, as well as the speed of replication and mutation, and conditions its adaptation to the environment and even to a new host (Chen et al., 2003), thus affecting the evolution of the virus (Smertina et al., 2019). It is also for the above reasons that $\mathrm{RdRp}$ may prove to be a more appropriate molecular target to track variability and phylogeny than the capsid protein (Koonim, 1991), as for example, the new RHDV2 genotypes reveal an increasing variability in their genome, which is due to recombination at the edge of structural and non-structural fragments, including RdRp (Lopes et al., 2018). To date, there has been no research carried out on the variability and phylogeny of RHDV (including RHDV, RHDVa, and RHDV2) based on RdRp. With the emergence of new RHDVa strains in Australia (Mahar et al., 2018b) and RHDV2 in the Macronesian Islands (Lopes et al., 2018) and Poland
(Fitzner \& Niedbalski, 2018), and due to the fact that RHDV2 has extended its infectious spectrum to hares, it seems crucial to monitor the variability of this virus for epidemiological reasons.

This study aimed at assessing genetic variability and performing a phylogenetic analysis of a total of 105 strains of Lagovirus europaeus, with RHDV and RHDV2 genotypes originating from around the world in the period of 1987-2017, pursuant to the nucleotide sequence of the RdRp coding gene. The aforementioned group included 14 strains whose RdRp sequences were obtained and analysed in this study (deposited by the author in GenBank), and other strains whose RdRp sequences were retrieved from GenBank: 74 strains classified as genotype GI.1 (RHDV), 14 as GI.2 (RHDV2), 2 strains of Lagovirus europaeus not assigned to any genotype, and a MRCV strain, the sequences of which were collected from GenBank.

\section{MATERIALS AND METHODS}

Lagovirus europaeus GI.1 (RHDV) strains. The research included 14 strains of Lagovirus europaeus, which according to the newly proposed classification and nomenclature system for Lagoviruses, are classified in group GI.1 (RHDV) (Table 1). All the strains originated from research centres in Europe, namely the Central Veterinary Institute, Institute of Debrecen, Hungary; the Collection of Animal Pathogenic Microorganisms, Veterinary Research Institute, Brno, Czech Republic; Friedrich-Loeffler Institute, Institut für Virusdiagnostik, Greifswald, Germany. RHDV strains used for the genetic studies were prepared in the form of a suspension in glycerol.

Isolation of viral RNA. Total RNA from fourteen RHDV strains were isolated from the suspension in glycerol using a High Pure Viral RNA Kit (Roche Diagnostic, Switzerland) according to the manufacturer's recommendations. RNA obtained in this manner was directly used for a reverse transcription reaction, or stored at $-80^{\circ} \mathrm{C}$ for further analysis.

Reverse transcription (RT) reaction - cDNA synthesis, PCR reaction and primers. A complementary strand of the nucleic acid (cDNA) of the gene encoding RdRp from 14 RHDV strains was obtained in the reverse transcription reaction on a matrix of viral RNA using the Reverse Transcriptase enzyme (RevertAid H Minus M-MuLV Reverse Transcriptase) (Fermentas, Lithuania). The reaction was performed using a reverse transcription kit - First Stand cDNA Synthesis Kit (Fermentas, Lithuania) with the following components: Random Hexamer primer at a concentration of $100 \mu \mathrm{M}$, dNTPs at10 mM, RevertAid H Minus M-MuLV Reverse Transcriptase-200U/ $\mu$ l, 5xReaction Buffer, RiboLock RNase inhibitor and water for molecular biology. For the reaction, RNA of the relevant strains $(24 \mathrm{~V}, 118 \mathrm{~V}$, 94VM, V411, 1600VM, 1042, V562, V560, 894V, 948V, $1447 \mathrm{~V}$, Wika, 72V, 237) (Table 1) was used. Before the reaction mixture was prepared, RNA of the 14 analysed RHDV strains was heated for 5 minutes at $65^{\circ} \mathrm{C}$, and then stored on ice until the mixture was prepared. The RT reaction was performed in a total volume of $20 \mu \mathrm{l}$ and included: $1.0 \mu \mathrm{l}$ of Random Hexamer primer, $6.0 \mu \mathrm{l}$ of water for molecular biology, $4.0 \mu$ l RT buffer, 1.0 $\mu l$ RiboLock Rnase inhibitor, $2.0 \mu \mathrm{l}$ dNTPs, $1.0 \mu \mathrm{l}$ RevertAid $H$ Minus M-MuLV Reverse Transcriptase, and $5.0 \mu \mathrm{l}$ RNA of the relevant strain (Table 1). The RT reaction was conducted in a T-gradient Thermocycler (Biometria, Germany) using the following temperature- 
Table 1. Lagovirus europaeus - GI. 1 (RHDV) strains evaluated in this study and subjected to analysis of genetic variability and phylogenetic analysis.

\begin{tabular}{|c|c|c|c|}
\hline No. & $\begin{array}{l}\text { Gl.1 (RHDV) strains } \\
\text { Country of origin/Year of identification }\end{array}$ & Host & $\begin{array}{l}\text { GenBank } \\
\text { accession number }\end{array}$ \\
\hline 1. & 24V_Hungary 1989 & Oryctolagus cuniculus & Banklt2247194/MN218422 \\
\hline 2. & 118V_Hungary 1989 & Oryctolagus cuniculus & Banklt2247194/MN218423 \\
\hline 3. & 94VM_Hungary1989 & Oryctolagus cuniculus & Banklt2247194/MN218424 \\
\hline 4. & V411_Austria1989 & Oryctolagus cuniculus & Banklt2247194/MN218425 \\
\hline 5. & 1600VM_Hungary1990 & Oryctolagus cuniculus & Banklt2247194/MN218426 \\
\hline 6. & 1042_Hungary1992 & Oryctolagus cuniculus & Banklt2247194/MN218427 \\
\hline 7. & V562_CzechR1992 & Oryctolagus cuniculus & Banklt2247194/MN218428 \\
\hline 8. & V560_CzechR1993 & Oryctolagus cuniculus & Banklt2247194/MN218429 \\
\hline 9. & 894V_Hungary1994 & Oryctolagus cuniculus & Banklt2247194/MN218430 \\
\hline 10. & 948V_Hungary1994 & Oryctolagus cuniculus & Banklt2247194/MN218431 \\
\hline 11. & 1447V_Hungary 1996 & Oryctolagus cuniculus & Banklt2247194/MN218432 \\
\hline 12. & Wika_Germany 1996 & Oryctolagus cuniculus & Banklt2247194/MN218433 \\
\hline 13. & $72 \mathrm{~V} \_$Hungary 2003 & Oryctolagus cuniculus & Banklt2247194/MN218434 \\
\hline 14. & 237_Austria2004 & Oryctolagus cuniculus & Banklt2247194/MN218435 \\
\hline
\end{tabular}

Due to the long strain names in the text, only the first part of the strain name was given. The sequences have been reported to GenBank and accepted, received accession numbers and will be made available in a public database at the time of publication.

time profile: $25^{\circ} \mathrm{C}-5$ minutes, $42^{\circ} \mathrm{C}-60$ minutes, $70^{\circ} \mathrm{C}$ -5 minutes and $4^{\circ} \mathrm{C}-1$ minute. cDNA samples were stored at $2-8^{\circ} \mathrm{C}$ until further analyses. The PCR reaction was prepared in a $25 \mu \mathrm{l}$ mixture containing: $2.0 \mu \mathrm{l}$ of the primer pair $(1.0 \mu \mathrm{l}$ each primer: RHDV _RTFor and RHDV_RTRev) (Sigma Aldrich, Germany), $1.0 \mu \mathrm{l}$ dNTPs (Fermentas, Lithuania), $2.5 \mu \mathrm{l}$ Taq Plus buffer (Genoplast, Poland), $0.5 \mu \mathrm{l}$ Taq plus DNA polymerase (Genoplast, Poland), $18.0 \mu \mathrm{l}$ of water for molecular biology (Eppendorf, Germany), and $1.0 \mu \mathrm{l}$ cDNA of the relevant RHDV strain (Table 1) added as the last component in the reaction mixture. The PCR reaction was performed in a Mastercycler proS Thermocycler (Eppendorf, Germany), applying the following amplification conditions: preliminary denaturation $-94^{\circ} \mathrm{C}-3 \mathrm{~min}$, and then 35 cycles comprised consecutively of: denaturation $\left(94^{\circ} \mathrm{C}-30 \mathrm{~s}\right)$, primer annealing $\left(63^{\circ} \mathrm{C}-1 \mathrm{~min}\right)$, chain elongation $\left(72^{\circ} \mathrm{C}-2 \mathrm{~min}\right)$; final elongation $\left(72^{\circ} \mathrm{C}\right.$ $-8 \mathrm{~min})$, and cooling of the reaction mixture to $4^{\circ} \mathrm{C}$. Reaction products were stored at $4^{\circ} \mathrm{C}$ until further analyses. Primers were designed on the basis of comparison of the nucleotide sequence encoding RdRp of the FRG RHDV strain (M67473) with the sequence of RHDV homologues. For amplification of the RdRp coding sequences (positioned in the genome at 3750-5350), the following primers were used: forward RHDV_RTFor 5'cactggcaagytgttggggttttc3', reverse RHDV_RTRev 5'gttccgggaactgatgctgtgg3'. A gene of length 1600 bp was amplified. Primer synthesis was performed by Sigma-Aldrich (Germany).

Electrophoresis of PCR products, preparative amplification and preparation of the RHDV genes for sequencing. For the purpose of visualisation of the PCR products, electrophoresis was performed in $2 \%$ agarose gels (Prona, USA) dyed with ethidium bromide (Fermentas, Lithuania). Molecular weight marker GeneRuler 200 bp (Fermentas, Lithuania) was used for evaluation of the size of the products. Interpretation of the electrophoretic analysis results was completed using a UV visualisation kit (UVP, Germany). After visualisation of the PCR reaction products, a preparative PCR reaction was performed to obtain the appropriate amount of products for sequencing. Conditions and the course of the reaction were identical to the conditions described above. After visualisation of the PCR products on a gel, they were isolated (from the gel) using the Gel-Out kit (A\&A Biotechnology, Poland), according to the manufacturer's protocol. The PCR products were then sent to Genomed, Poland, for sequencing.

Comparative analysis of nucleotide sequences of the gene encoding RdRp, creation of the distance matrices and the phylogenetic tree. The obtained 1284 nucleotide-long sequences of the gene encoding RdRp from the 14 RHDV strains were deposited in GenBank (Table 1). Comparative analysis of these nucleotide sequences involved a total of 105 Lagovirus europaeus strains (Tables 1 and 2), as generated by the MEGA 5.0 software, permitting genetic variability to be determined by generation of a distance matrix. Analyses were conducted using the Maximum Composite Likelihood model (Tamura et al., 2004) with the MEGA 5.0 software (Kumar et al., 2018). Variability within the nucleotide and amino acid sequences of RdRp was determined against a reference sequence of the V351 strain (U54983). Supplementary Table S1 and Table S2 (at https://ojs.ptbioch.edu.pl/index. $\mathrm{php} / \mathrm{abp} /$ ) show this variability also with respect to other reference strains from 1989: FRG (M67473), AST89 (Z49271), SD (Z295514), BS89 (X87607). The distance matrix shows the genetic distances for all sequence pairs within the range of 0.000 to 1.000. Genetic distance (manifesting genetic variability) between the sequences of a pair of strains corresponds to the number of nucleotide substitutions (expressed as a percentage) which occurred in such sequences since their divergence from the output sequence. For a clear presentation of the test results, genetic variability is expressed as percentage. Distance matrix tables (Supplementary Material - Table S1 at https://ojs.ptbioch.edu.pl/index.php/abp/) show the values of nucleotide substitutions, which correspond to the percentage of genetic variation. 
Table 2. Lagovirus europaeus strains obtained from GenBank and used for the genetic variability and phylogenetic analyses.

\begin{tabular}{|c|c|c|c|c|}
\hline No. & $\begin{array}{l}\text { Lagovirus europaeus } \\
\text { genotype }\end{array}$ & Strain, origin and year of identification & Host & $\begin{array}{l}\text { GenBank } \\
\text { accession } \\
\text { number }\end{array}$ \\
\hline 1. & \multirow{45}{*}{$\begin{array}{l}\text { Gl.1 } \\
\text { (RHDV) }\end{array}$} & V-351_CzechR1987 & Oryctolagus cuniculus & U54983 \\
\hline 2. & & KGM_Poland 1988 & Oryctolagus cuniculus & KP144790 \\
\hline 3. & & PD_Poland1989 & Oryctolagus cuniculus & KP144789 \\
\hline 4. & & FRG_Germany 1989 & Oryctolagus cuniculus & M67473 \\
\hline 5. & & BS89_Italy1989 & Oryctolagus cuniculus & X87607 \\
\hline 6. & & SD_France1989 & Oryctolagus cuniculus & Z29514 \\
\hline 7. & & AST89_Spain1989 & Oryctolagus cuniculus & Z49271 \\
\hline 8. & & Eisenhuttenstadt_Germny1989 & Oryctolagus cuniculus & EF558578 \\
\hline 9. & & Mexico89_Mexico1989 & Oryctolagus cuniculus & AF295785 \\
\hline 10. & & Italy90_Italy 1990 & Oryctolagus cuniculus & EU003579 \\
\hline 11. & & Korea90_Korea1990 & Oryctolagus cuniculus & EU003580 \\
\hline 12. & & Ascot_UnitedKingdom 1992 & Rabbit & EF558575 \\
\hline 13. & & Meiningen_Germany1993 & Oryctolagus cuniculus & EF558577 \\
\hline 14. & & Jena_Germany1993 & Oryctolagus cuniculus & EF558576 \\
\hline 15. & & MAŁ_Poland1994 & Oryctolagus cuniculus & KU882093 \\
\hline 16. & & BLA_Poland1994 & Oryctolagus cuniculus & KP144792 \\
\hline 17. & & CB137_Pt_PortugalAlpiarca1995 & Oryctolagus cuniculus algirus & JX886002 \\
\hline 18. & & Saudia Arabia_SaudiaArabia1996 & Oryctolagus cuniculus & DQ189078 \\
\hline 19. & & Frankfurt5_Germany1996 & Rabbit & EF558573 \\
\hline 20. & & Frankfurt12_Germany1996 & Rabbit & EF558572 \\
\hline 21. & & Hartmannsdorf_Germany1996 & Rabbit & EF558586 \\
\hline 22. & & Triptis_Germany 1996 & Rabbit & EF558583 \\
\hline 23. & & JXCHA97_China1997 & Rabbit & DQ205345 \\
\hline 24. & & GSK_Poland1998 & Oryctolagus cuniculus & KU882092 \\
\hline 25. & & Lagovirus europaeus_France 2000 & Oryctolagus cuniculus & MH190418.1 \\
\hline 26. & & Daschwald_Germany2000 & Rabbit & EF558582 \\
\hline 27. & & Erfurt_Germany2000 & Rabbit & EF558581 \\
\hline 28. & & lowa_USA2000 & Rabbit & AF258618 \\
\hline 29. & & ZD0_Poland 2000 & Oryctolagus cuniculus & KU882095 \\
\hline 30. & & Bahrain_Bahrain2001 & Rabbit & DQ189077 \\
\hline 31. & & NY01_USA2001 & Rabbit & EU003581 \\
\hline 32. & & UT01_USA2001 & Rabbit & EU003582 \\
\hline 33. & & Rossi_Germany2002 & Rabbit & EF558584 \\
\hline 34. & & Whnrh_China2002 & Rabbit & DQ280493 \\
\hline 35. & & Hokkaido_Japan2002 & Rabbit & AB300693 \\
\hline 36. & & OPO_Poland2004 & Oryctolagus cuniculus & KU882094 \\
\hline 37. & & CD_China2004 & Rabbit & AY523410 \\
\hline 38. & & GRZ2004_Poland2004 & Oryctolagus cuniculus & KP144791 \\
\hline 39. & & L145_Poland2004 & Oryctolagus cuniculus & KY679902 \\
\hline 40. & & KRY_Poland2004 & Oryctolagus cuniculus & KY319033 \\
\hline 41. & & W147/05_Poland2005 & Oryctolagus cuniculus & KY319035 \\
\hline 42. & & IN05_USA2005 & Rabbit & EU003578 \\
\hline 43. & & HYD_China2005 & Rabbit & JF412629 \\
\hline 44. & & CB194Pt_PortugalChaves2006 & Oryctolagus cuniculus algirus & JX886001 \\
\hline 45. & & AUS/NSW/M9/2007_Australia2007 & Oryctolagus cuniculus & KX357678 \\
\hline
\end{tabular}




\begin{tabular}{|c|c|c|c|c|}
\hline \multirow[b]{2}{*}{46.} & & & & \\
\hline & & AUS/NSW/M2/2007_Australia2007 & Oryctolagus cuniculus & KX357677 \\
\hline 47. & & Sch07_China2007 & Rabbit & KY171748 \\
\hline 48. & & NZ61_NewZealand2008 & Rabbit & EF558580 \\
\hline 49. & & NZ54_NewZealand2008 & Rabbit & EF558579 \\
\hline 50. & & AUS/SA/ORA383/2008_Australia2008 & Oryctolagus cuniculus & KX357695 \\
\hline 51. & & AUS/ACT/PI-1/2009_Australia2009 & Oryctolagus cuniculus & KX357672 \\
\hline 52. & & AUS/ACT/GUN1-52/2009_Australia2009 & Oryctolagus cuniculus & KX357668 \\
\hline 53. & & AUS/ACT/GUN1-37/2009_Australia2009 & Oryctolagus cuniculus & KX357667 \\
\hline 54. & & AUS/ACT/AIN-2/2009 & Oryctolagus cuniculus & KX357654 \\
\hline 55. & & AUS/ACT/AIN-1/2009 & Oryctolagus cuniculus & KX357653 \\
\hline 56. & & NJ2009 & Rabbit & HM623309 \\
\hline 57. & & AUS/ACT/MtPt-4/2010 & Oryctolagus cuniculus & KX357671 \\
\hline 58. & & AUS/ACT/MtPt-2/2010 & Oryctolagus cuniculus & KX357670 \\
\hline 59. & & STR2012 & Oryctolagus cuniculus & KF677011 \\
\hline 60. & & STR2-2013 & Oryctolagus cuniculus & KY679904 \\
\hline 61. & & SKO2013 & Oryctolagus cuniculus & KY319034 \\
\hline 62. & & GLE2013 & Oryctolagus cuniculus & KY319032 \\
\hline 63. & & RED1-2013 & Oryctolagus cuniculus & KY679903 \\
\hline 64. & & AUS/NSW/BER1/2013/12_Australia2013 & Domestic rabbit & KY628307 \\
\hline 65. & & AUS/NSW/BER2/2013/12_Australia2013 & Domestic Rabbits & KY628309 \\
\hline 66. & & AUS/NSW/BER3/2014/01_Australia2014 & Domestic Rabbits & KY628310 \\
\hline 67. & & AUS/NSW/BlueGums1/2014/03_Australia2014 & Wild rabbit & KT006732.1 \\
\hline 68. & & AUS/NSW/OUR1/2014/06_Australia2014 & Wild rabbit & KY628318 \\
\hline 69. & & AUS/NSW/OUR2/2014/06_Australia2014 & Wild rabbit & KY628319 \\
\hline 70. & & STR2014_Poland2014 & Oryctolagus cuniculus & KY679905 \\
\hline 71. & & BIE2015_Poland2015 & Oryctolagus cuniculus & KY319031 \\
\hline 72. & & AUS/NSW/WAL1/2015/01_Australia2015 & Domestic Rabbits & KY628320 \\
\hline 73. & & HB_China2016 & Rabbit & KY437668 \\
\hline 74. & & CBMad17-1_PortugalMadeiraFunchal2017 & Oryctolagus cuniculus & MF407655 \\
\hline 75. & \multirow{14}{*}{ GI.2 (RHDV2) } & RHDV-N11_SpainNavarra2011 & Oryctolagus cuniculus & KM878681 \\
\hline 76. & & Zar11-11_Spain,2011 & Oryctolagus cuniculus & KP129398 \\
\hline 77. & & CBVal16_PortugalValpacos2012 & Oryctolagus cuniculus & KM979445 \\
\hline 78. & & Rij06-12_Spain2012 & Oryctolagus cuniculus & KP129395 \\
\hline 79. & & Seg08-12_Spain2012 & Oryctolagus cuniculus & KP129396 \\
\hline 80. & & Tar06-12_Spain,2012 & Oryctolagus cuniculus & KP129397 \\
\hline 81. & & Zar06-12_Spain,2012 & Oryctolagus cuniculus & KP129399 \\
\hline 82. & & 16PLM1_SpainCanarylslandsLa Palma2016 & Oryctolagus cuniculus & MF407653 \\
\hline 83. & & CBMad17-2_PortugalMadeiraPaulSerra2017 & Oryctolagus cuniculus & MF407656 \\
\hline 84. & & CBMad173_PortugalMadeira PaulSerra2017 & Oryctolagus cuniculus & MF407657 \\
\hline 85. & & PSM2_PortugalMadeiraPortoSanto2016 & Oryctolagus cuniculus & MF407654 \\
\hline 86. & & CBPico17-1_PortugalAzoresPico2017 & Oryctolagus cuniculus & MF407651 \\
\hline 87. & & CBPico17-2_PortugalAzoresPico2017 & Oryctolagus cuniculus & MF407652 \\
\hline 88. & & CBAlgarve14-3/2014_PortugalAlgarve2014 & Rabbit & KM115715.2 \\
\hline 89. & Gl. (RCV) & MRCV & Rabbit & GQ166866 \\
\hline 90. & \multirow{2}{*}{$\begin{array}{l}\text { Strains not assigned } \\
\text { to any genotype }\end{array}$} & P19_PortugalPorto1994 & Oryctolagus cuniculus & KY765610 \\
\hline 91. & & P95_PortugalToresNovas 1996 & Lepus granatensis & KJ943791 \\
\hline
\end{tabular}

Due to the long strain names in the text, only the first part of the strain name was given. 
The evolutionary history was inferred using the Maximum Likelihood method and General Time Reversible model (Nei \& Kumar, 2000), the most statistically appropriate method for the selected data. A discrete Gamma distribution was used to model the evolutionary rate differences among sites. Evolutionary analyses were conducted with MEGA 5.0 (Kumar et al., 2018). Reliability of phylogenetic trees were assessed using the bootstrap method $(\%)$. Distance matrices were also developed (using the method stipulated above) for particular groups of the strains generated in the phylogenetic tree in order to determine the intra-group variability. In the last phase, the nucleotide sequences of the 105 RHDV strains were translated to amino acid sequences, and a distance matrix was generated to determine their variability using the MEGA 5.0 software (Kumar et al., 2018).

\section{RESULTS}

\section{Genetic variability of Lagovirus europaeus strains}

Nucleotide sequences of genes coding RdRp, obtained in this study from 14 Lagovirus europaeus strains, with the GI.1 genotype (RHDV), (Table 1), had a length of 1284 nucleotides and covered positions 3955-5238 in the viral genome, while the full RdRp coding sequence has a length of 1548 nucleotides and occupies positions 37565301. Genetic variation of the 14 analysed strains within RdRp indicated occurrence of many polymorphic sites with local mutations in the form of transitions ( $\mathrm{C} \leftrightarrow \mathrm{T}$, $\mathrm{G} \leftrightarrow \mathrm{A})$ and transversions $(\mathrm{G} \leftrightarrow \mathrm{T}, \mathrm{A} \leftrightarrow \mathrm{T}, \mathrm{C} \leftrightarrow \mathrm{G})$. Transitions were more frequent, comprising over $90 \%$ of mutations, involving frequent $\mathrm{C} \leftrightarrow \mathrm{T}$ changes (over 50\%) versus $\mathrm{G} \leftrightarrow \mathrm{A}$. Among the $10 \%$ of transversions, all mutations occurred with a comparable frequency.

Among the 14 analysed strains (Table S1 at https:// ojs.ptbioch.edu.pl/index.php/abp/), the highest variability within the RdRp gene was presented in the Austrian 237 strain from 2004, which showed a genetic distance of 0.124 from the reference V351 strain from 1987 (12.4\% nucleotide substitutions, Table S1 at https://ojs.ptbioch. edu.pl/index.php/abp/). The genetic distance between the Austrian 237 strain and the remaining thirteen strains ranged from 0.117 to 0.123 (from $11.7 \%$ to $12.3 \%$ nucleotide substitutions). A lower genetic variability was observed for the Hungarian strains from 1994 and 1996 - $1447 \mathrm{~V}(8 \%)$, and $894 \mathrm{~V}, 948 \mathrm{~V}(7.6 \%)$; and the German Wika strains from 1996 (6.9\%). The lowest variability, however, was recorded for: Hungarian strains from 1990, 1989, 1992, 2003 - 1600VM (1.1\%), 24V, 118V, 94VM, 1042, 72V (1.3\%); Austrian from 1989 - V411 (1.2\%), and Czech from 1992 and 1993 - V562 (1.3\%), V560 (1.6\%). Supplementary Table S2 (at https://ojs.ptbioch. edu.pl/index.php/abp/)presents a matrix for the comparison of the predicted $428 \mathrm{RdRP}$ amino acid sequences in the 105 analysed Lagovirus europaeus strains. The RdRp amino acid sequence obtained in this study was at positions 1316-1743, which constituted over $80 \%$ of the full RdRp amino acid sequence. Among the 14 strains analysed here, the highest genetic variability in the amino acid sequence versus the V351 strain, was observed for Wika $(2.4 \%)$ and the 237 strain $(1.9 \%)$. In the case of strains 24V89, 118V, 94VM, V411, V562, 1600VM, and $72 \mathrm{~V}$, variability was at $0.9 \%$. For other strains from the $1990 \mathrm{~s}$, however, the variability was as follows: $1447 \mathrm{~V}$ $(1.7 \%), 1042(1.4 \%), \operatorname{V} 560(1.2 \%), 894 \mathrm{~V}(1.7 \%), 948 \mathrm{~V}$ $(1.7 \%)$.
Analysis of the 105 Lagovirus europaeus strains genetic variability (Table S1 at https://ojs.ptbioch.edu.pl/index. $\mathrm{php} / \mathrm{abp} /$ ) on the basis of the RdRp gene revealed that the strains have an increasing genetic distance, observed both in the time scale and in the geographic scale, with the highest genetic variability in the area of RdRp gene recorded for five strains: three from Australia- AUS/ NSW/BER-2, AUS/NSW/BER-3, AUS/NSW/WAL-1 from 2013, 2014, 2015, one from Portugal - CBMad17-1 from 2017, and one MRCV strain. The above strains from Australia and Portugal showed a genetic distance from $36.2 \%$ to $37.8 \%$ versus the V351 sequence, amounting to, respectively: $36.2 \%$ for AUS/NSW/BER-2 and AUS/NSW/WAL-1, $36.3 \%$ for AUS/NSW/BER-3, $37.8 \%$ for CBMad17-1. Equally high variability in this group was recorded for MRCV: $35.4 \%$ (vs. V351), 34.7\% (vs. FRG), $37.2 \%$ (vs. AST89), $37.9 \%$ (vs. AST89), and $36.9 \%$ (vs. BS89). Among the 105 analysed strains (Table S2 at https://ojs.ptbioch.edu.pl/index.php/abp/), the highest variability (based on the RdRp amino acid sequence) was recorded in five strains, including three from Australia, one from Portugal (Madera), and the MRCV strain (12-13.0\%). Assessed against the V351 sequence, the results were as follows: $12.0 \%$ for AUS/ NSW/BER-2 and AUS/NSW/WAL-1; $12.5 \%$ for AUS/ NSW/BER-3/2014 and 13.0\% for CBMad17-1. Equally high variability was recorded for MRCV: $12.3 \%$ (vs. V351), $11.6 \%$ (vs. FRG), $11.8 \%$ (vs. AST89 and SD) and $12.0 \%$ (vs. BS89).

The high variability, not previously reported, within the RdRp gene was obtained for eight Lagovirus europaeus strains with the GI.2 genotype (RHDV2), isolated in 2011, 2012 and 2016, originating from Portugal and Spain (Table S1 at https://ojs.ptbioch.edu.pl/index.php/ $\mathrm{abp} /$ ). The above strains revealed a genetic distance of $15.8 \%$ for Rij06-12, $15.9 \%$ for RHDV-N11; $16.1 \%$ for CBVal16; $16.1 \%$ for Tar06-12; $16.3 \%$ for Zar06-12; $16.3 \%$ for Zar11-11; $16.4 \%$ for Seg08-12, and $16.5 \%$ for 16PLM1. A lower genetic variability $(11.1 \%-12.9 \%)$ of the GI.2 genotype (RHDV2) (Table S1 at https://ojs. ptbioch.edu.pl/index.php/abp/) was reported for strains from Portuguese islands in 2016-2017 - 12.1\% for CBMad17-3 and PSM2, 12\% for CBMad17-2, 12.9\% for CBPico17-2 and CBPico17-1; and one strain of CBAlgarve14-3 from 2014 from mainland Portugal - 11.1\%. On the basis of the RdRp amino acid sequence (Table S2 at https://ojs.ptbioch.edu.pl/index.php/abp/), the RHDV2 strains revealed a genetic distance versus V351 ranging from $2.8 \%$ to $3.1 \%: 2.8 \%$ for Rij06-12, Zar06-12, Zar11-11 and 3.1\% for RHDV-N11, CBVal16, Tar0612, Seg08-12, 16PLM1. For other Portuguese strains in this genotype, the variability ranged from $1.7 \%$ to $2.6 \%$ (1.7\% for CBMad17-2 and CBAlgarve14-3/2014, 1.9\% for CBMad17-3 and PSM2 and 2.6\% for CBPico17-2 and CBPico17-1).

Genetic variability for two Portuguese strains, P19 from 1994 and P95 from 1996, which so far have not been assigned to any genotype, were $14.7 \%$ and $14.8 \%$, respectively (Table $\mathrm{S} 1$ at https://ojs.ptbioch.edu.pl/index.php/abp/). The lowest genetic variability among the Portuguese strains was for CB137_Pt-8.5\% and CB194_ Pt-10.5\% (Table S1 at https://ojs.ptbioch.edu.pl/index. php/abp/). The P95 and P19 strains showed 3.1\% variability in the RdRp amino acid sequence, similarly to some RHDV2 strains. The lowest genetic variability among the Portuguese strains was observed for CB137 Pt-1.4\% and CB194_Pt-2.6\% (Table S2 at https://ojs. ptbioch.edu.pl/index.php/abp/). 
A genetic variability of $11.8-13.6 \%$ within RdRp was obtained for 28 strains from around the world from the period of 1996-2014, and classified as GI.1a (G6/RHDVa) (Table S1 at https://ojs.ptbioch.edu.pl/index.php/ $\mathrm{abp} /$ ). The genetic distance versus the V351 sequence was as follows: $11.8 \%$ nucleotide substitutions for the Hartmannsdorf strain, $12.1 \%$ for Erfurt and Rossi, 12.2\% for IN05, $12.3 \%$ for UT01, 12.4\% for Hokkaido and GRZ2004, 12.5\% for Triptis and Red1-2013, 12.6\% for JXCha97, as well as W147_05 and NY01, 12.7\% for Daschwald, $12.8 \%$ for Iowa, $12.9 \%$ for L145, as well as KRY and NJ2009, 13.0\% for CD and HYD, as well as for Sch07, 13.1\% for GLE2013 and STR-2-2013, 13.2\% for WHNRH, 13.4\% for SKO and STR2014, and 13.4\% for BIE2015, 13.6\% for STR2012, and $12.4 \%$ for the Austrian 237 strain analysed here. Based on the RdRp amino acid sequence, the genetic distance of the above 28 strains with respect to the $\mathrm{V}-351$ sequence ranged from $2.1 \%$ to $2.6 \%$ (Table S2 at https://ojs.ptbioch.edu. $\mathrm{pl} /$ index.php/abp/).

A lower genetic variability within RdRp was recorded for strains isolated in the 1980s, 1990s, and after 2000 (Table S1 at https://ojs.ptbioch.edu.pl/index.php/abp/). Genetic distance for strains from the 1980 s (including the strains analysed in this study) versus V351 ranged from $0.9 \%$ to $7.6 \%$, and was as follows: $0.9 \%$ for FRG, $1.0 \%$ for KGM, $1.1 \%$ for PD, $1.2 \%$ for $\mathrm{V} 411,1.3 \%$ for $24 \mathrm{~V} 89,118 \mathrm{~V}$, and $94 \mathrm{VM}, 2.8 \%$ for Mexico89, 6.5\% for BS89, 7.0\% for Eisenhuttenstadt, $7.2 \%$ for AST89 and 7.6\% for SD. Strains from the 1980 s showed a $0.9-1.2 \%$ variability in the RdRp amino acid sequence (Table S2 at https://ojs.ptbioch.edu. $\mathrm{pl} /$ index.php/abp/).

Genetic distance for strains from the 1990s (including strains analysed in this study) versus V351 ranged from $1.0 \%$ to $8.0 \%$, and was as follows: $1.0 \%$ for MAL, $1.1 \%$ for $1600 \mathrm{VM}, 1.3 \%$ for 1042 and V562, $1.5 \%$ for Italy $90,1.6 \%$ for V $560,2.6 \%$ for Korea- 90 , 4.5\% for SaudiaArabia, 6.9\% for Wika, 6.6\% for Meiningen and BLA, 6.8\% for Frankfurt5 and Frankfurt12, 6.9\% for Ascot, 7.6\% for $894 \mathrm{~V}, 948 \mathrm{~V}$ and Jena, $7.8 \%$ for GSK, and $8.0 \%$ for $1447 \mathrm{~V}$. Genetic distance for strains from the 1990s versus V351, determined on the basis of the RdRp amino acid sequences, and including strains analysed in this study, ranged from $0.9 \%$ to $2.4 \%$ (Table S2 at https://ojs. ptbioch.edu.pl/index.php/abp/).

Genetic distance for strains isolated after 2000 (including 14 Australian strains) versus V351 ranged from $1.3 \%$ to $8.4 \%$, and was as follows: $1.3 \%$ for $72 \mathrm{~V}, 2.2 \%$ for $\mathrm{HB}, 2.5 \%$ for NZ54 and NZ61, 3.4\% for AUS/SA/ ORA383, 3.4\% for AUS/ACT/PI-1, $4.3 \%$ for AUS/ $\mathrm{NSW} / \mathrm{M} 2,4.5 \%$ for AUS/ACT/MtPt-4 and AUS/ NSW/M9, 4.7\% for AUS/ACT/MtPt-2, 4.8\% for AUS/ ACT/AIN-2 and AUS/ACT/AIN-1, 5.0\% for AUS/ ACT/GUN1-37 and AUS/ACT/GUN1-52, 6.0\% for AUS/NSW/BlueGums1 and AUS/NSW/BER1, $6.7 \%$ for OPO, $6.8 \%$ for AUS/NSW/OUR-1 and AUS/NSW/OUR-2, $7.8 \%$ for Lagovirus europaeus_ France2000, 8.1\% for ZD0, 8.4\% for Bahrain. Variability in the group of the above 14 Australian strains from the period of 2007-2014 ranged from 3.4\% to 6.8\%. Genetic distance for strains isolated after 2000, based on the RdRp amino acid sequences, ranged from $0.9 \%$ to $1.9 \%$. The Australian strains versus V351 revealed a distance of $1.4 \%-1.9 \%$ (Table S2 at https://ojs.ptbioch.edu.pl/index. $\mathrm{php} / \mathrm{abp} /)$.

\section{Phylogenetic analysis of the Lagovirus europaeus strains}

The image of phylogenetic interdependencies (Fig. 1) among 105 Lagovirus europaeus strains, build on the basis of RdRp, has revealed a clear division of these strains into 7 groups, where the 14 strains analysed in this study were allocated into GI.1c (G2), GI.1d (G3-G5), and GI.1a (RHDVa) groups. Distance matrices generated for groups of Lagovirus europaens strains (Table S3-S9 at https://ojs.ptbioch.edu.pl/index.php/abp/), isolated pursuant to the topology of the phylogenetic tree (Fig. 1), revealed that variability in $\mathrm{RdRp}$ within the groups (intra-group variability) is much lower than variability obtained for all 105 Lagovirus europaeus strains. Lower variability was caused by much lower numbers of nucleotide substitutions in such groups.

Group GI.1b (G1) included 11 strains from the period 1989-2017, namely the last 28 years, and these were the strains isolated in the first period of the disease occurrence in Europe, as well as contemporary strains from continental Portugal and the Portuguese islands. Evolutionary relations in this group clearly point to a chronological distance that has divided the strains into two subgroups. The first has been formed by RHDV from 1989-SD, AST89, Eisenhuettenstadt, with CB137_ Pt from 1995 and CB194_Pt from 2006. While the latter by Portuguese strains from the period of 2014-2017: PSM2, CBMad17-3, CBMad17-2, CBPico17-2, CBPico17-1, CBAlgarve14-3. The distance matrix generated to determine intragroup genetic variability (Table S3 at https://ojs.ptbioch.edu.pl/index.php/abp/) revealed variability ranging between $0.2-9.7 \%$. The shortest genetic distance in this group was recorded, mutually, for strains CBMad17-3 from 2017 and PSM2 from 2016 (0\% nucleotide substitutions), and then for CBPico 17-1 and CBPico17-2 from 2017, and for CBMad 17-2 and CBMad 17-3 from 2017 (in both cases $0.2 \%$ nucleotide substitutions), as well as AST89 and Eisenhuettenstadt (0.9\%). Portuguese strain CB137Pt showed a genetic distance to strains in its subgroup between $3.1-3.5 \%$, and to other Portuguese strains between 6.8-9.7\%.

Group GI.1c (G2) was comprised of 35 strains (including nine strains analysed in this study) from the period of 1987-2014, originating from around the world, including Australia. Evolutionary relations in this group divided the strains into three subgroups. The first subgroup included European strains phylogenetically deriving from the Czech V351 strain from 1987, which included nine strains analysed in this study, as well as the following strains: Italy 90, PD, KGM, MAL, FRG. The second subgroup included strains from New Zealand and Australia. The third subgroup included HB, Korea-90, Mexico89, and SaudiaArabia (Fig. 1). Intragroup variability (Table S4 at https://ojs.ptbioch.edu.pl/ index.php/abp/) ranged from $0 \%$ to $8.8 \%$. The shortest genetic distance in this group was recorded for strains NZ54 and NZ61 (0\%), 72V and 94VM (0\%), V351 and FRG $(0.9 \%)$. The most genetically distanced from other strains in this group were the four Australian strains from 2013 and 2014, which revealed a genetic distance of $5.7-8.8 \%$.

Group GI.1d (G3-G5) was comprised of 16 strains (including four strains analysed in the course of this study) from the period of 1989-2004, predominantly originating from Europe, and one from Asia. Evolutionary relations in this group divided the strains into two subgroups. Subgroup one included Wika, Frankfurt15, Frankfurt12, BLA, and OPO. Subgroup two: BS89, Ascot, Meiningen, Lagovirus europaeus, Bahrain, Jena, 


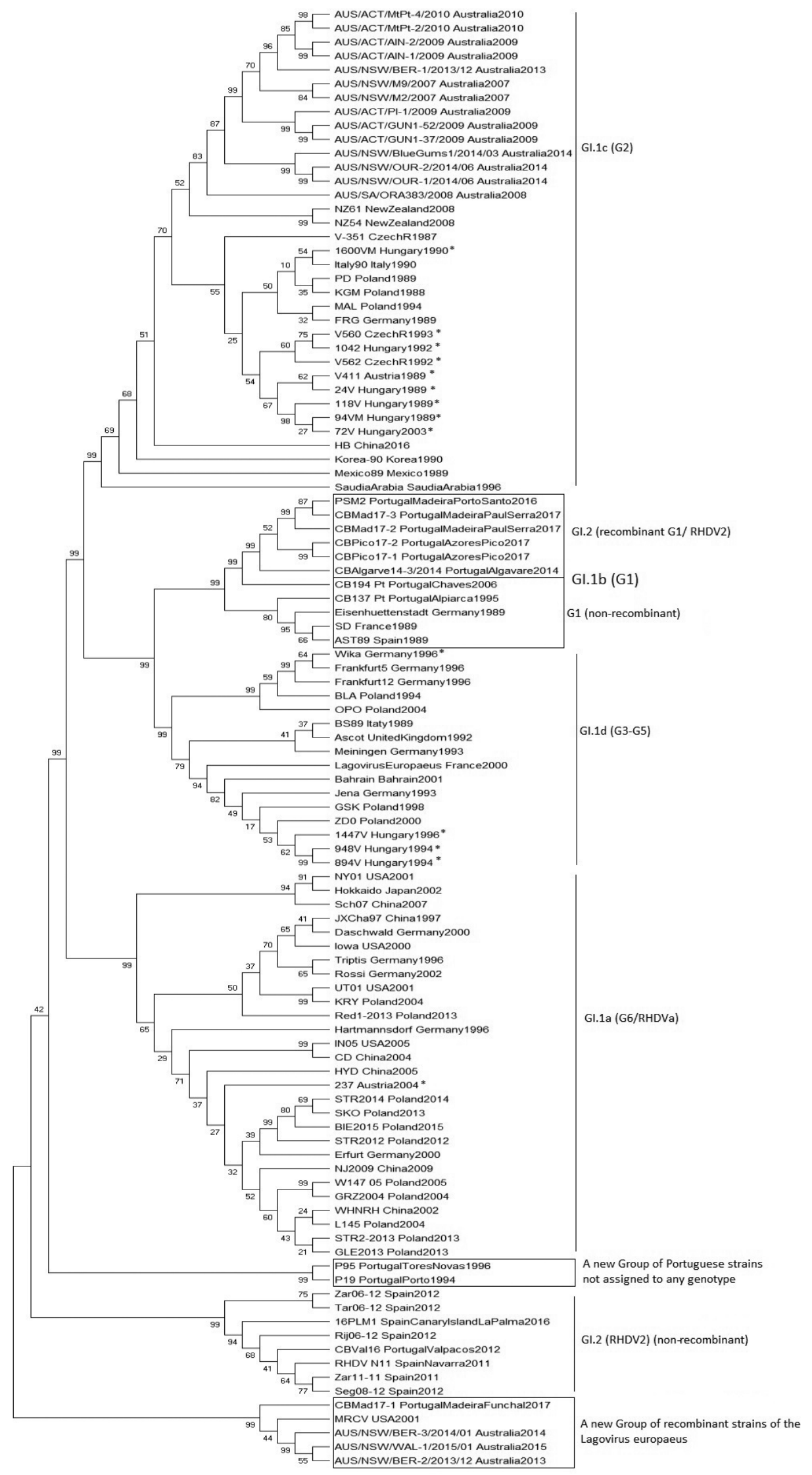

Figure 1. Phylogenetic tree of 105 strain of Lagovirus europaeus build on the basis of the RdRp coding gene nucleotide sequence. The evolutionary history was inferred by using the Maximum Likelihood method and General Time Reversible model. Evolutionary analyses were conducted with MEGA 5.0. Reliability of the phylogenetic trees was assessed using the bootstrap method (\%). 
GSK, ZD0, 1447, 948V, 894V. Intragroup variability (Table S5 at https://ojs.ptbioch.edu.pl/index.php/abp/) totalled $0-5.0 \%$. The shortest genetic distance in the group was recorded for strains $894 \mathrm{~V}$ and $984 \mathrm{~V}(0 \%)$, Frankfurt5 and Frankfurt12 $(0.2 \%)$, as well as Wika, Frankfurt5 and Frankfurt12 (0.2\%), BLA and OPO $(0.5 \%)$. The most genetically distanced were the French Lagovirus europaeus and Bahrain. Lagovirus europaeus recorded a large genetic distance versus BS89 (3.5\%), As$\cot (3.6 \%)$, Meiningen (3.7\%), BLA (3.9\%), Wika (4.5\%), Frankfurt12 and Frankfurt 5 (4.4\%). Similarly, Bahrain recorded a genetic distance versus BS89 (3.9\%), Ascot (4.0\%), Meiningen (4.0\%), BLA (4.4\%), Wika (5.0\%), Frankfurt12 and Frankfurt 5 (4.9\%).

Group GI.1a (G6/RHDVa) was comprised of 28 strains (including 1 strain analysed in this study) from the period of 1996-2015, originating from around the world. The strains in this phylogenetic group were divided into three subgroups. Subgroup one was comprised of: NY01, Hokkaido, Sch07; subgroup two: JXCha97, Daschwald, Iowa, Triptis, Rossi, UT01, KRY, RED12013, and subgroup three: Austrian 237, Hartmannsdorf, IN05, CD, HYD, STR2014, SKO, BIE2015, STR2012, Erfurt, NJ2009, W14705, GRZ2004, WHNRH, L145, STR2-2013, GLE2013. The location of the 237 strain in this particular group testifies to it being a GI.1a variant. Intragroup variability totalled $0.2-6.1 \%$ (Table S6 at https://ojs.ptbioch.edu.pl/index.php/abp/). The shortest genetic distance in this group was recorded for strains STR2014 and SKO (0.2\%), BIE2015 and STR2014 $(0.3 \%)$, SKO and STR2012 (0.5\%), STR2014 and STR2012 (0.6\%), Rossi and Triptis (0.9\%). The most genetically distanced in this group was strain $\mathrm{Sch} 07$, recording a significant genetic distance from most strains: Hokkaido (3.0\%), NY01 (3.7\%), JXCha97 (3.8\%), Triptis (4.0\%), Rossi (4.3\%), Iowa (4.3\%), Daschwald (4.6\%), Red1-2013 (5.1\%), Erfurt (5.4\%), UT01 (5.4\%), 237 (5.5\%), L145 (5.5\%), KRY (5.5\%), STR2-2013 (5.7\%), BIE2015 (5.7\%), Hartmannsdorf (5.7\%), GRZ2004 (5.8\%), W147_05 (5.8\%), NJ2009 (5.8\%), IN05 (5.9\%), SKO $(5.9 \%)$, WHNRH $(6.0 \%)$, CD $(6.0 \%)$, HYD $(6.0 \%)$, STR2012 (6.0\%), STR2014 (6.0\%), GLE2013 (6.1\%).

The image of phylogenetic relations based on RdRp clearly pointed to a new monophyletic group situated between GI.1a-1d and RHDV2, with a high statistical support (bootstrap value 99\%). It was created by two strains of the Portuguese origin: P95_PortugalToresNovas1996 (host: Lepus granatensis) and P19_PortugalPorto1994 (host: Oryctolagus cuniculus), which so far have not been assigned to any genotype. The strains (Table S7 at https://ojs.ptbioch.edu.pl/index.php/abp/) revealed a genetic distance from one another of $0.017 / 1.7 \% \mathrm{nu}-$ cleotide substitutions.

Group GI.2 (RHDV2) was formed by eight strains from the period of 2011-2016, originating from Spain and Portugal. The strains were divided into two subgroups: one from 2012: Zar06-12, Tar06-12, and the other from 2011-2016: 16PLM1, Rij0612, CBVal16, RHDVN11, Zar11-11, Seg08-12. Intragroup variability (Table S8 at https://ojs.ptbioch.edu.pl/index.php/abp/) ranged from 0.5 to $4.1 \%$. The shortest genetic distance in this group was recorded for RHDV_N11 versus Zar11$11(0.5 \%)$, Seg08-12 (0.7\%), and Rij06-12 (0.9\%), and mutually between CBVal16 and Rij06-12 (0.9\%). The most distanced in the group was Tar06-12 from 2012, which showed a significant genetic distance versus Rij06$12(3.1 \%)$, CBVal16 (3.2\%), and 16PLM1 (4.1\%), as well as Zar06-12 and 16PLM1 (3.6\%).
The picture of phylogenetic dependencies based on the RdRp gene revealed a new group of recombinant strains of Lagovirus europaeus (Fig. 1), with high bootstrap support values $(99 \%)$. Phylogenetic dependences in this group suggest that the Portuguese and Australian strains are associated with MRCV (chosen as the reference strain in this analysis) and the Portuguese strain is additionally associated with RHDV2. Intragroup variability (Table S9 at https://ojs.ptbioch.edu.pl/index.php/abp/) totalled $0.5-17.5 \%$ (exclusive of MRCV) and $0.5-18.3 \%$ (inclusive of MRCV). The shortest genetic distance was recorded, mutually, for Australian strains: AUS/NSW/ BER-2 versus AUS/NSW/WAL $(0.2 \%)$, AUS/NSW/ BER-2 versus AUS/NSW/BER-3 (0.5\%), as well as AUS/NSW/WAL-1 vs. AUS/NSW/BER-3 (0.7\%). Portuguese CBMad17-1, in turn, revealed a very large genetic distance versus Australian strains AUS/NSW/WAL-1 $(17.3 \%)$ and versus AUS/NSW/BER-2 and AUS/NSW/ BER-3 (17.5\%). It must be noted that CBMad17-1 was found to be the most genetically distanced from MRCV $(18.3 \%)$, which was a greater distance than recorded in respect to the remaining strains, namely: AUS/NSW/ BER-2 (16.2\%), AUS/NSW/BER-3 (16.4\%) and AUS/ NSW/WAL-1 (16.4\%).

\section{DISCUSSION}

Genetic variability of viruses depends on the frequency of mutations taking place in the genome, and external factors of the environment where the pathogens are present (Belshaw et al., 2008). The core natural factor that conditions a mutation comes from errors in imprecise replication of nucleic acids by $\mathrm{RdRp}$. This polymerase is incapable of repairing errors occurring during synthesis of descendant RNA strands (Steinhauer et al., 1992). The scale of errors is illustrated by an example where one error occurs per one replication cycle for RNA viruses as compared to one error per 300 cycles for DNA viruses (Smertina et al., 2019). Genetic variability can also result from other mechanisms, such as homological recombination between closely related RNA viruses. The pace of recombination seems to vary and be specific to each virus species, as some recombine very frequently, while others seem to be limited, showing little proof of recombination (Forrester et al., 2008). The emergence of a new genotype or variant in the case of RNA viruses most frequently involves mutations within the RdRp gene or within the capsid genome, particularly the subunit encoding surface epitopes, with the new genotype being more or less virulent or more stable in the environment (Capucci et al., 1998; Belshaw et al., 2008; Bigoraj et al., 2011). Studies on genetic variability of RHDV, among others conducted on the basis of the VP60-coding gene, revealed both - mutations and recombinations (Abrantes et al., 2008; Forrester et al., 2008; Hukowska-Szematowicz et al., 2013; Lopes et al., 2015b; Mahar et al., 2016; Hu et al., 2017; Lopes et al., 2018). It is suggested that the rabbit plague outbreak recorded in China in 1984 was caused by recombination of the genetic material originating from the Angora rabbits imported from Germany. This variability type was also identified for three RHDV strains in the RdRp gene (Forrester et al., 2008). According to some authors, such RHDV variability type as recombination will be increasingly frequent in viral evolution because the recombinants can be characterised with higher pathogenicity and different tropism than the input strains (Abrantes et al., 2008; Forrester et al., 2008; Lopes et al., 2015b), and the phenomenon begins to play an im- 
portant role in generating biological diversity of RHDV2 (Lopes et al., 2015b).

Analysis of genetic variability in 105 Lagovirus europaeus strains, based on the RdRp gene, indicated that these strains feature an increasing genetic distance, observed both in the time scale and in geographic scale, while RHDV variability occurs both, through mutation and recombination, which is a consequence of employing the existing genetic diversity to develop new genome combinations (Lopes et al., 2017). The results of the analyses point out that the highest mutation potential in the studied RdRp gene (15.8-16.5\%) was recorded for the RHDV2 genotype in Portugal and Spain. The results indicate that these are non-recombinant RHDV2 strains. Smertina and others (Smertina et al., 2019) speculated that RHDV2 in Australia could have acquired a relative fast polymerase, which may explain its higher virulence, and apparent evolutionary success. During 18 months from arrival, RHDV2 had largely replaced the endemic RHDV strains in Australia (Mahar et al., 2018a). Therefore, replication speed may mark viral efficiency because viruses with a higher replication speed can produce more copies of its genome, resulting in a greater number of variants, even if RdRp error rate remains the same (Smertina et al., 2019). Lower mutation potential within the area of the RdRp gene was observed for strains classified as GI.1a (G6) (11.8-13.6\%), GI.1c (G2) (1.0-6.8\%) and GI.1d (G3-G5) (6.5-8.4\%). The mutation potential, however, of the Australian strains in GI.1c (G2) from the period of 2007-2014 totalled 3.4-6.8\%, which points to the fact that the mutation coefficient in RdRp had increased in the Australian population of the virus. A very interesting situation was found for some strains (PSM2, CBMad17-3, CBMad17-2, CBPico17-2, CBPico17-1, CBAlgarve14-3/2014) identified in 2014, 2016 and 2017 in GI.1b (G1), which showed variability at $11.1-12.9 \%$, similar to GI.1a (G6/RHDVa) (11.8-13.6\%), but phylogenetically were not found in this group. This suggests that these are G1/RHDV2 recombinants, which is in line with the results of previous studies (Mahar et al., 2016; Lopes et al., 2018; Silverio et al., 2018). Genetic variations of $7.0-10.5 \%$ of the remaining strains (CB194Pt, CB147 Pt, Eisenhuettenstadt, SD, AST89) in this group, supported by the results of studies by other authors (Abrantes et al., 2012; Lopes et al., 2017), indicate that these are the G1-non-recombinant strains, both within the studied polymerase gene and in the VP60 and VP10 genes (Lopes et al; 2017). Genetic variability of $14.7 \%$ and $14.8 \%$ in the RdRp gene was observed in the case of Portuguese strains P95 and P19, which may have been the source of a new variant of polymerase which did not stabilize in the environment. On the other hand, very high genetic variability, which may indicate recombination of genetic material between rabbit viruses, was observed for CBMad-17-1 (37.8\%), AUS/NSW/BER-3 (36.3\%) and AUS/NSW/BER-2 and AUS/NSW/NAL1 strains $(36.2 \%)$.

The highest variability within the amino acid sequence of RdRp was recorded for recombinant strains $(12.0-13.0 \%)$ and MRCV (12.3\%). High variability was observed for RHDV2 genotype (2.8-3.1\%) and recombinants P19 and P95 (3.1\% for both strains), and then in group GI.1a (RHDVa) (2.1-2.6\%), in GI.1b (G1) for strains from continental Portugal and Portuguese islands $(1.4-2.6 \%)$, and for strains from the $1980 \mathrm{~s}(0.9-1.2 \%)$, the 1990s $(0.9-2.4 \%)$, and after $2000(0.9-1.9 \%)$, including Australian strains $(1.4 \%$ to $1.9 \%)$. However, discussions in this area seem to be problematic, given that no similar studies have been conducted.
The matrix of phylogenetic relations (Fig. 1) among the 105 Lagovirus europaeus strains on the basis of RdRp gene sequence has revealed a clear division of the strains into 7 groups. The allocation to the groups depended on chronology, geographic origin, and evolutionary events in the viral history, such as recombination. The location of some strains on the phylogenetic tree, supported by their variability results, testifies to them being recombinants, forming phylogenetically new groups, while recombination seems to be an increasingly frequent event in the viral evolution (Lopes et al., 2018). Such a situation applies to two strains of the Portuguese origin: P95 and P19. On the phylogenetic tree, the strains are positioned between GI.1a-1d and RHDV2 and have not been assigned to any genotype. Their location on the phylogenetic tree indicates that this is a new group of recombinant strains which "for a moment" appeared in Portugal. Phylogenetic analysis by Lopes and others (Lopes et al., 2017) showed that in the region of the genome encoding structural proteins VP60 and VP10, the strains were similar to pathogenic strains from the GI.1b group (G1), but in the region of the genome that encodes non-structural proteins they had created a new group which was $13 \%$ divergent from known strains. According to Lopes and others (Lopes et al., 2017), there are no further reports of this strain surviving in the environment. The absence of information could be due to limited sampling (Lopes et al; 2017). Another important issue is the fact that the P95 strain was isolated from an Iberian hare (Lepus granatensis), which points to breaching the species barrier, although for some unknown reason the infection was not sustained in the environment (Lopes et al., 2017). Perhaps the occurrence of this strain line can be explained with the survival strategy of the virus through speciation in one of two directions, namely: change of the infected host species or through a change within the same host species. The former strategy which probably occurred in the case of P95 required many changes and was a major adaptation challenge, hence the virus did not survive. One must also account for the fact that perhaps, in the case of the two strains, there was a similar situation as that was observed in the noroviruses (Mahar et al., 2013), where recombination resulted in a new RdRp variant with a higher mutation potential (14.8\% and $14.7 \%$ nucleotide substitutions, respectively, for P95 and P19). This was supposed to imply a higher genetic variability of RHDV and improved general robustness of the viral population against the selection pressure but, for unknown reasons, this mechanism has failed (Mahar et al., 2013).

The GI.1b (G1) group contains strains that are similar in two ways. On one hand, the groups were created by chronology, as it contains the "classical" strains of RHDV from 1989 and strains CB137 from 1995 and CB194 from 2006, which probably are evolutionarily related to classical strains (Abrantes et al., 2012). On the other hand, this group also includes the G1/RHDV2 recombinant strains currently circulating in the Portuguese islands and replacing the existing G1 strains in the wild rabbit population (Lopes et al., 2015a). It should be noted that the CBAlgarve14-3 strain, in a phylogenetic analysis based on the VP60 gene sequence (Lopes et al., 2015a; Mahar et al., 2016), showed positioning in the RHDV2 genotype, i.e. behaved differently than in our study. This fact underlines the importance of research not only on genes encoding structural proteins such as VP60, but also of non-structural proteins such as RdRp, in order to determine the designation of strains to genotypes. In group GI.1c (G2), strains were characterised 
with both, a chronological structure: from the period of 1987-1996, and a geographic structure: strains from Australia from the period of 2007-2014, and from New Zealand. Evolutionary relations of Australian and New Zealand strains point to them as being descendants of a European ancestor, the Czech V351 strain, which was artificially released in the mid-1990s in Australia and New Zealand to control the population of the artificially introduced European Rabbit (Cooke \& Fenner, 2002; Eden et al., 2015). Furthermore, evolutionary relations in this group point out that all of the remaining strains forming this group derive from the Czech V351 strain. Group GI.1d (G3-G5) was predominantly formed by European strains from the period of 1989-2004, with some of them focusing around the Italian Bs89 strain from 1989. It must be pointed out that this group also included strains which, in prior studies (Forrester et al., 2008), were found to have undergone recombination in the RdRp-coding region, including: Frankfurt5, Frankfurt12, and Wika, but this event did not result in a durable new RdRp variant. Among the strains analysed, 28 originating from the period of 1996-2015 had formed a monophyletic group GI.1a (G6/RHDVa), statistically very well supported, with a variability of $11.8-13.6 \%$, with intragroup variability totalling $0.2-6.1 \%$.

Phylogenetic relations deduced from the RdRp gene had revealed a new phylogenetic group, gathering original non-recombined RHDV2 strains from the period of 2011-2016 circulating in Spain, continental Portugal and the Canary Islands (Lopes et al., 2018; Silverio et al., 2018). The last group in the phylogenetic tree was formed by four strains from Australia, one from Portugal, and by MRCV. Phylogenetic relations in this group suggest that currently the population of Lagovirus is mixed between Europe and Australia, as also reported by other authors (Mahar et al., 2016). Phylogenetic relations in this group and genetic variability suggest that the Portuguese CBMad17-1 strain from 2017 is a recombinant that arose between rabbit caliciviruses and RHDV2, although the occurrence of the strain in Madera still remains a mystery. Positioning of Australian strains AUS/ NSW/BER-3, AUS/NSW/BER-2, and AUS/NSW/ WAL-1 on the phylogenetic tree points to their phylogenetic relations with rabbit calciviruses, and suggests they are recombinants of rabbit caliciviruses and RHDV or rabbit caliciviruses and RHDV or RHDVa, because Australian RHDV strains have been gradually replaced since 2013 with the GI.1a variant (Mahar et al., 2018a).

\section{CONCLUSIONS}

The extent and significance of genetic variability through RNA mutation and recombination has not yet been thoroughly investigated, and the study presented here approximates this issue to some extent, which is important in the context of viral evolution, epidemiology and pathogenesis. So far, the main direction of genetic variation and evolution of RHDV which has been present worldwide for over 30 years, has led from RHDV, through RHDVa, to RHDV2. It seems that the recorded variability within the RdRp gene for the analysed lagoviruses, in particular RHDV2, is of major importance for its expansion and survival in the environment.

\section{REFERENCES}

Abrantes J, Lopes AM, Esteves PJ (2012) Complet genomic sequences of rabbit haemorrhagic disease virus G1 strains isolated in the
European rabbit original range. J Virol 86: 13886. https://doi. org/10.1128/JVI.02683-12

Abrantes J, Esteves PJ, Van der Loo W (2008) Evidence for recombination in the major capsid gene VP60 of the rabbit haemorrhagic disease virus (RHDV). Arch Virol 153: 329-335. https://doi. org/10.1007/s00705-007-1084-0

Abrantes J, Lopes AM, Dalton KP, Melo P, Correira JJ. Ramada M, Alves PC, Parra F, Esteves PJ (2013) New variant of rabbit hemorrhagic disease virus, Portugal, 2012-2013. Emerg Infect Dis 19: $1900-$ 1902. https://doi.org/10.3201/eid1911.130908

Baily JL, Dagleish MP, Graham M, Maley M, Rocchi MS (2014) RHDV variant 2 presence detected in Scotland. Vet Rec 174: 411. https://doi.org/10.1136/vr.g2781

Bell DJ, Davis JP, Gardner M, Barlow AM, Rocchi M, Gentil M, Wilson R (2019) Rabbit Haemorrhagic disease virus type 2 in hare in England. Vet Rec 184: 127-128. https://doi.org/10.1136/vr.1337

Belshaw R, Garden A, Rambaut A, Pybus OG (2008) Pacing a small cage: mutation and RNA viruses. Trends Ecol Evol 23: 188-193. https://doi.org/10.1016/j.tree.2007.11.010

Bigoraj E, Chrobocińska M, Kwit E (2011) Genetic diversity and recombination of noroviruses. Med Weter 67: 802-807

Calvete C, Sarto P, Calvo AJ, Montroy F, Calvo JH (2014) Could the new rabbit haemorrhagic disease virus variant (RHDVb) be fully replacing classical RHD strains in the Iberian Peninsula? Word Rabbit Sci 22: 9. https://doi.org/10.4995/wrs.2014.1715

Camarda A, Pugliese N, Cavadini P, Circella E, Capucci L, Caroli A, Legretto M, Mallia E, Lavazza A (2014) Detection of the new emerging rabbit haemorrhagic disease type 2 virus (RHDV2) in Sicily from rabbit (Oryctolagus cuniculus) and Italian hare (Lepus corsicanus). Res Vet Sci 97: 642-645. https://doi.org/10.1016/j.rvsc.2014.10.008

Capucci L, Fallacara F, Grazioli S, Lavazza A, Lodovica Pacciarini M, Brocchi EA (1998) Further step in the evolution of rabbit hemorrhagic disease virus: the appearance of the first consistent antigenic variant. Virus Res 58: 115-126. https://doi.org/10.1016/s011681702(98)00106-3

Chen Xi, Feng Q, Wu Z, Liu Y, Hunag K, Shi R, Chen S, Lu W, Ding M, Collins RA, Fung YW, Lau LT, Yu AC, Chen J (2003) RNA-dependent RNA polymerase gene sequence from foot-and mouth disease virus in Hong Kong. Biochem Biophys Res Commun 308: 899-905. https://doi.org/10.1016/s0006-291x(03)01511-0

Cooke BD, Fenner F (2002) Rabbit haemorrhagic disease and biological control of wild rabbits, Oryctolagus cuniculus, in Australia and New Zealand. Wildl Res 29: 689-706. https://doi.org/10.1071/WR02010

Dalton KP, Nicieza I, Abrantes J, Esteves PJ, Parra F (2014) Spread of new variant RHDV in domestic rabbits on the Iberian Peninsula. Vet Microbiol 169: 67-73. https://doi.org/10.1016/j.vetmic.2013.12.015

Dalton KP, Nicieza I, Balseiro A, Muguerza MA, Rosell JM, Casais R, Alvarez AL, Parra F (2012) Variant rabbit hemorrhagic disease virus in young rabbits, Spain. Emer Infect Dis 18: 2009-2012. https://doi. org/10.3201/eid1812.120341

Duarte M, Henriques M, Barros SC, Fagulha T, Ramos F, Luis T, Fevereiro M, Benevides S, Flor L, Barros SV, Bernardo S (2015) Detection of RHDV variant 2 in the Azores. Vet Rec 76: 130. https:// doi.org/10.1136/vr.h2402

Eden JS, Kovaliski J, Duckworth JA, Swain G, Mahar JE, Strive T, Holmes EC (2015) Comparative phylodynamics of rabbit hemorrhagic disease virus in Australia and New Zealand. J Virol 89: 85488558. https://doi.org/10.1128/JVI.01100-15

Fitzner A, Niedbalski W (2017) Phylogenetic analysis of rabbit haemorrgafic disease virus (RHDV) strains isolated in Poland. Arch Virol 162: 3197-3203. https://doi.org/10.1001/s00705-017-3476-0

Fitzner A, Niedbalski W (2018) Detection of rabbit haemorrhagic disease virus 2 (GI.2) in Poland. Pol J Vet Sci 21: 451-458. https://doi. org/10.24425/122618

Forrester NL, Moss SR, Turner SL, Schirrmeier H, Gould EA (2008) Recombination in rabbit haemorrhagic disease virus: Possible impact on evolution and epidemiology. Virology 376: 390-396. https:// doi.org/10.1016/j.virol.2008.03.023

Hall RN, Peacock DE, Kovaliski J, Mahar JE, Mourant R, Piper M, Strive T (2017) Detection of RHDV2 in European brown hares (Lepus europaeus) in Australia. Vet Rec 180: 121. https://doi. org/10.1136/vr.104034

Hall RN, Mahar JE, Haboury S, Stevens V, Holmes EC, Strive T (2015) Emerging rabbit hemorrhagic disease virus 2 (RHDVb), Australia. Emerg Infect Dis 21: 2276-2278. https://doi.org/10.3201/ eid2112.151210

Holmes EC, Grenfell BT (2009) Discovering the phylodynamics of RNA viruses. PLoS Comput Biol 5: e1000505. https://doi. org/10.1371/journal.pcbi.1000505

Hu B, Wang F, Fan Z, Song Y, Abrantes J, Zuo Y, Esteves PJ (2017) Recombination between G2 and G6 strains of rabbit hemorrhagic disease virus (RHDV) in China. Arch Virol 162: 269-272. https:// doi.org/10.1007/s00705-016-3082-6

Hukowska-Szematowicz B, Tokarz-Deptuła B, Deptuła W (2013) Analysis of genetic variability and phylogenetic analysis of select- 
ed Czech and French strain of rabbit haemorrhagic disease virus (RHDV). J Appl Genetic 54: 235-248. https://doi.org/10.1007/ s13353-013-0140-6

Kerr PJ, Kitchen A, Holmes EC (2009) The origin and phylodynamics of rabbit haemorrhagic disease virus. J Virol 83: 12129-12138. https://doi.org/10.1128/JVI.01523-09

Kinnear M, Linde CC (2010) Capsid gene divergence in rabbit hemorrhagic disease virus. J Gen Virol 91: 174-181. https://doi. org/10.1099/vir.0.014076-0

Koonim EV (1991) The phylogeny of RNA-dependent RNA polymerase of positive-strand RNA viruses. J Gen Virol 72: 2197-2206. https://doi.org/10.1099/022-1317-72-9-2197

Kumar S, Stecher G, Li M, Knyaz C, Tamura K (2018) MEGA X Molecular Evolutionary Genetics Analysis across computing platforms platforms. Mol Biol Evol 35: 1547-1549. https://doi.org/10.1093/ molbev/msy096

Le Gall-Recule G, Lavazza A, Marchandeau S, Bertagnoli S, Zingelstein F, Cavadini P, Martinelli N, Lombardi G, Guerin JL, Lemaitre E et al. (2013) Emergence of new lagovirus related to rabbit haemorrhagic disease virus. Vet Res 44: 81. https://doi.org/10.1186/12979716-44-81

Le Gall-Recule G, Zwingelstein F (2011) Detection of a new variant of rabbit haemorrhagic disease virus in France. Vet Res 168: 137-138. https://doi.org/10. 1136/vr.d697

Le Gall-Recule G, Zwingelstein F, Laurent S, de Boisseson C, Portejoie Y, Rasschaert D (2003) Phylogenetic analysis of rabbit haemorrhagic disease virus in France between 1993 and 2000, and the characterization of RHDV antigenic variants. Arch Virol 148: 65-81. https:/ /doi.org/10.1007/s00705-002-0908-1

Le Pendu J, Abrantes J, Bertagnoli S, Guitton JS, Le Gall-Recule G, Lopes AM, Marchandeau S, Alda F, Almeida T, Celio AP et al. (2017) Proposal for a unified classification system and nomenclature of lagoviruses. J Gen Virol 98: 1658-1666. https://doi.org/10.1099/ jgv.0.000840

Liu SJ, Xue HP, Pu BQ, Quian NH (1984) A new viral disease in rabbits. Anim Husb Vet Med 16: 253-255

Lopes AM, Silverio D, Magalhaes MJ, Areal H, Alves PC, Esteves PJ (2017) Characterization of old RHDV strains by complete genome sequencing identifies a novel genetic group. Sci Rep 7: 13599. https://doi.org/10.1038/s41598-017-13902-2

Lopes AM, Blanco-Aguiar J, Martin-Alonso A, Leitao M, Foronda P, Mendes M, Goncalves D, Abrantes J, Esteves PJ (2018) Full genome sequences are key to disclose RHDV2 emergence in the Macaronesian islands. Virus Genes 54: 1-4. https://doi.org/10.1007/ s11262-017-1523-2

Lopes AM, Correira J, Abrantes J, Melo P, Ramada M, Magalhaes MJ, Alves PC, Esteves PJ (2015a) Is the new variant RHDV replacing genogroup 1 in Portuguese wild rabbit populations? Viruses 7: 2736. https://doi.org/10.3390/v7010027

Lopes AM, Dalton KP, Magalhaes MJ, Parra F, Esteves PJ, Holmes EC (2015b) Full genomic analysis of new variant rabbit hemorrhagic disease virus revealed multiple recombination events. J Gen Virol 96: 1309-1319. https://doi.org/10.1099/vir.0.000070

Lopes AM, Marques S, Silva E, Magalhaes MJ, Pinheito A, Alves PC, Le Pendu J, Esteves P J, Thompson G, Abrantes J (2014) Detection of RHDV strains in the Iberian hare (Lepus granatensis): earliest of rabbit lagovirus cross-species infection. Vet Res 45: 94. https:// doi.org/10.1186/s13567-014-0094-7
Mahar JE, Bok K, Green KY, Kirkwood CD (2013) The importance of intergenic recombination in norovirus GII.3 evolution. J Virol 87: 3687-3698. https://doi.org/10.1128/JVI.03056-12

Mahar JE, Hall RN, Peacock D, Kovaliski J, Piper M, Mourant R (2018a) Rabbit Haemorrhagic Disease Virus 2 (RHDV2; GI.2) is replacing endemic strains of RHDV in the Australian Landscape within 18 Months of its arrival. I Virol 92: e01374-17. https://doi. org/10.1128/JVI.01374-17

Mahar JE, Nicholson L, Eden JS, Duchene S, Kerr PJ, Duckworth J, Ward VK, Holmes EC, Strive T (2016) Bening rabbit caliciviruses exhibit similar evolutionary dynamics to their virulent relatives. J Virol 90: 9317-9329. https://doi.org/10.1128/JVI.01212-16

Mahar JE, Read AJ, Gu X, Urakova N, Mourant R, Piper M, Haboury S, Holmes EC, Strive T, Hall RN (2018b) Detection and circulation of a novel rabbit haemorrhagic disease virus in Australia. Emerg Infect Dis 24: 22-31. https://doi.org/10.3201/eid2401.170412

Nei M, Kumar S (2000) Molecular Evolution and Phylogenetics. Oxford University Press, New York.

Neimanis A, Ahola H, Pettersson UL, Lopes AM, Abrantes J, Zohari S, Esteves P, Gavier-Widen D (2018) Overcoming spcecies barriers: an outbreak of Lagovirus europaeus GI.2/RHDV2 in an isolated population of mountain hare (Lepus timidus). BMC Vet Res 14: 367. https://doi.org/1186/s12917-018-1694-7

Puggioni G, Cavadini P, Maestrale C, Scivoli R, Botti G, Ligios C, Le Gall-Recule G, Lavazza A, Capucci L (2013) The new French 2010 rabbit haemorrgagic disease virus causes an RHD-like disease in the Sardinian Cape hare (Lepus capensis mediterraneus). Vet Res 44: 96. https://doi.org/10.1186/1297-9716-44-96

Rahali N, Sghaier S, Kbaier H, Zanati A, Bahloul C (2019) Genetic characterization and phylogenetic analysis of rabbit hemorrhagic diasease virus isolated in Tunisia from 2015-2018. Arch Virol 164: 2327-2332. https://doi.org/10.10007/s00705-019-04311-z.

Rouco C, Abrantes J, Serronha A, Lopes AM, Maio E, Magalhaes MJ, Blanco E, Barcena J, Esteves PJ, Santos N, Alves PC, Monterroso P (2018) Epidemiology of RHDV2 (Lagovirus europaeus/GI.2) in free-living wild European rabbits in Portugal. Transbound Emerg Dis 65: e373-e382. https://doi.org/10.1111/tbed.12767

Silverio D, Lopes AM, Melo-Ferreira J, Magalhaes MJ, Monterroso P, Serronha A, Maio E, Alves PC, Esteves PJ, Abrantes J (2018) Insights into the evolution of the new variant rabbit haemorrhagic disease virus (GI.2) and the identification of novel recombinant strains. Transbound Emerg Dis 65: 983-992. https://doi.org/10.1111/ tbed. 12830

Smertina E, Urakova N, Strive T, Frese M (2019) Calicivirus RNADependent RNA Polymerase: evolution, structure, protein dynamics, and function. Front Microbiol 10: 1280. https://doi.org/10.3389/ fmicb.2019.01280

Steinhauer DA, Domingo E, Holland JJ (1992) Lack of evidence for proofreading mechanisms associated with an RNA virus polymerase. Gene 122: 281-288. https://doi.org/10.1016/0378-1119(92)90216-c

Tamura K, Nei M, Kumar D (2004) Prospects for inferring very large phylogenies by using the neighbor-joining method. PNAS 101: 11030-11035. https://doi.org/10.1073/pnas.0404206101

Westcott DG, Frossard JP, Everest D, Dastjerdi A, Duff JP, Steinbach F, Choudhury B (2014) Incursion of RHDV2-like variant in Great Britain. Vet $\operatorname{Rec} 174:$ 333. https://doi.org/10.1136/vr.g2345 